How to cite this article:

Ahmad, I., Said, H., \& Mohamad Nor, F. (2019). Exploring service-learning practices: Evidence from Pakistan vocational education. Malaysian Journal of Learning and Instruction, 16(2), 125-154.

\title{
EXPLORING OUTCOMES OF SERVICE-LEARNING PARTICIPATION: EVIDENCE FROM PAKISTAN
}

\author{
${ }^{1}$ Iqbal Ahmad, ${ }^{2}$ Hamdan Said \& ${ }^{3}$ Faizah Mohamad Nor \\ ${ }^{1}$ Faculty of Education, University of Malakand, Pakistan \\ ${ }^{2}$ School of Education, Universiti Teknologi Malaysia, Malaysia \\ ${ }^{3}$ Language Academy, Universiti Teknologi Malaysia, Malaysia
}

Corresponding author: p-hamdan@utm.my

Received: 14/8/2019 Revised: 3/12/2019 Accepted: 10/12/19 Published: 24/12/2019

\begin{abstract}
Purpose - This study explored the perspectives of teachers on outcomes of service-learning participation in vocational training institutes. The main purpose was to gain a better understanding of outcomes concerning service-learning participation of vocational training institute students in Pakistan.

Methodology - A total of 315 respondents participated in the study. Data were collected from 15 randomly selected vocational training institutes using a self-designed questionnaire which was drafted and validated after expert approval. The construct validation of the questionnaire was established through Exploratory Factor Analysis.

Findings - The findings indicated that participation in servicelearning resulted in increased course content knowledge, the development of interpersonal skills, and the development of a volunteering attitude among the vocational institute students.

Significance - This study is one of the few studies related to academic outcomes of vocational education students as a result of service-learning participation. The results facilitate understanding
\end{abstract}


of the pedagogical role of service-learning as a practical teaching approach, and would be of particular interest to employers who are looking for skilled manpower in the current job market.

Keywords: Service-learning practices, learning outcomes, vocational training institutes.

\section{INTRODUCTION}

Service-learning is defined as a credit-bearing, experiential educational method that allows students to work in collaboration, develop a sense of civic responsibility, gain new knowledge and skills by reflecting on the service activity as well as provide service to the community (Bringle \& Hatcher, 1995). Service-learning started as a community-based internship in the 1960s, but the focus has shifted from merely offering service to the community to becoming responsible citizens who possess professional skills. Currently, service-learning activities are increasingly centred on cooperative experiences to promote collaboration and civic responsibility among students. Students are engaged to work collaboratively in solving complex problems of their communities (Felten \& Clayton, 2011; Metzger \& Ferris, 2013). Research has consistently listed the multiple gains of service-learning on students' social, civic and leadership development (Gershenson-Gates, 2012; Steinberg \& Norris, 2011; Warren, 2012), civic knowledge and awareness of social issues (Melchior \& Bailis, 2002), political awareness and efficacy (Billig, Root, \& Jesse 2005), sense of civic efficacy (Kahne $\&$ Westheimer, 2006), civic participation (Lambright, 2008), civic skills and abilities (Althof \& Berkowitz, 2006), and community awareness, problem solving skills and civic responsibility (Eyler, Giles, \& Braxton, 1997).

Theoretically, service-learning stems from the pragmatist theory of John Dewey who considered education as an experience and active participation in society. This theory links learning to work experience to prepare students for the changes and challenges in life. The idea led to the birth of service-learning in the $60 \mathrm{~s}$ and 70s (Birdwell, Scott, \& Horley, 2013; Denby, 2008). As an education method, service-learning hinges upon the constructivist 
and experiential learning theory of David Kolb (Kolb, Boyatzis, \& Mainemelis, 2001). The constructivist paradigm considers learning as an active and constructive process. This theory explains that students derive meaning and create new knowledge by applying their skills and knowledge in real-life contexts (Billig, 2012). Kolb's experiential learning model also terms learning as a constructive process in which students identify a problem, plan to solve it, apply the plan in a real-life situation, get the results and reflect on them. This cycle truly represents the nature of service-learning (Kolb, 2005). Apart from Dewey and Kolb, this study also draws upon the works of Eyler and Giles (1999) and Wang and Jackson (2005), who describe civic knowledge, skills, values, efficacy, commitment and responsibility as direct outcomes of service-learning. Thus, it is established that service-learning extends new experiences from the traditional classroom to real-life contexts where students work and learn to collaboratively develop their teamwork skills and civic responsibility (Blouin \& Perry, 2009; Falk, 2012). Today's society increasingly looks for skilled and civically responsible citizens (Calvert \& Kurji, 2012). To address this need, researchers have suggested that collaboration should be developed among schools, communities and the world of work (Deeley, 2010; Llenares \& Deocaris, 2018). As a community-based learning approach, servicelearning effectively achieves this goal (Ahmad \& Said, 2016; Eyler et al., 1997; Gerstenblatt \& Gilbert, 2014; Robinder, 2012).

Dewey believed that students learn better citizenship skills when they are engaged in community-based service (Einfeld \& Collins, 2008) which instils in its participants richer experiences that result from connectivity to real-life situations, elements that learners do accumulate from traditional educational systems but are somehow inadequate. This points to Dewey's emphasis on the inclusion of 'experience' and 'practice' as ingredients of the process of active learning (Ehrlich, 1998; Rocheleau, 2004). As an academic pedagogy, service-learning develops students' problem-solving skills and citizens' civic-mindedness. It also helps them to become active and informed citizens (Eyler et al., 1997; Furco, 2010; Hurd, 2008; Jacobson, Oravecz, Falk, \& Osteen, 2011; Warren, 2012). According to Stanton (1987), the major goals of service-learning include contributing toward social reform through reciprocity, collaboration and teamwork. 
The literature shows that interpersonal and communication skills are the most important life skills required for graduates to find employment in today's job market (Abdul Karim et al., 2012; Gershenson-Gates, 2012; Idris, Ariffin, \& Mohd Ishak, 2009; Tucker, McCarthy, Hoxmeier, \& Lenk, 1998; Veloo, Md-Ali, \& Chairany, 2016). Many studies have reported that service-learning enhances students' communication skills during the course of the community service experience, when the students interact among themselves and with community members (Assendelft, 2008; Jernstedt, OlmShipman, \& Reed, 2003). Service-learning also enhances one's inter-personal and problem-solving skills (Crossman \& Kite, 2007; Sheil \& Bahk, 2010), leadership skills (Couse \& Russo, 2006; Pedler, 2011), and understanding and vision of leadership (Astin \& Sax, 1998; Pless, Maak \& Stahl, 2011; Simons \& Cleary, 2006).

Service-learning is a useful tool to bring about positive attitudinal changes in students regarding their perception and understanding of social issues in society (Jacobson et al., 2011). More so, this change can be seen in students' perspectives of social justice and its implementation. As a result of service experience, students become aware of structural inequalities and other related issues in society. For example, they can critique the process of distribution of resources in society and make their voices heard on issues of justice and discrimination of race, colour and creed (Said, Ahmad, Tahir, Ahmad, \& Hassan, 2013; Teranishi, 2007). When students learn about the process of social structures of the community, they examine and critically reflect on their own assumptions and on the biases practised in their society. The critical examination of prevailing practices and social structures develops their understanding of diversity and social justice, which is one of the major outcomes of service-learning (Baldwin, Buchanan, \& Rudisill, 2007; O’Grady, 2014).

\section{Vocational Training Institutes}

Vocational training institutes are schools where job-related learning takes place for raising people's productivity both during on-thejob and off-the-job training (Tsang, 1997). Generally, vocational training is a part of vocational education, that gives some specialised professional knowledge and skills to students in a vocational school or institute (Mortaki, 2012). This type of education combines 
knowledge, skills, problem-solving and entrepreneurship for preparing students for creativity and production of innovative ideas (Chappell, 2003). The basic aim of vocational education is to prepare students for different professional jobs. It focuses on human capital development to improve the productivity of the labour force of the country (Kazmi, 2007). In other words, vocational training enhances the efficiency and skills of labour, and prepares students for better participation in economic development. Along with professional skills development, vocational education students also develop attitudes, values and behaviours that enable them to become informed citizens and productive workers (Chappell, 2003).

Based on the aforementioned advantages of vocational education, the governments of many countries invest huge amounts of money in vocational training (Kincheloe, 1999). Unlike other types of education which put much emphasis on the theoretical aspects of teaching and learning, vocational education focuses on hands-on learning experiences (Phillips, 2011). Vocational education uses not only classrooms, but also laboratories and field-related experiences for creating a learning atmosphere that enables the students to apply their skills and knowledge in real-world situations.

Vocational education is based on the premise that a quality work force begins with strong professional skills (Phillips, 2011). Despite this noble philosophy, the outcomes of vocational education in many South Asian countries have produced mixed results. Countries such as Japan, Singapore and South Korea are the best examples of having the most developed vocational educational system (Aggarwal, 2013). Vocational education graduates from these countries are well-received by employers and are offered many employment opportunities and packages (Ul-Haq, 2000). Unlike in Japan, Singapore, and South Korea, the vocational education system in South Asian countries including India, Bangladesh and Pakistan needs further refinement and direction (Alam, 2015; Kemal, 2005). For Pakistan, many studies have shown that skill development is the most neglected area (Aggarwal, 2013; Alam, 2015; Javied \& Hyder, 2009). Numerous efforts have been initiated to put more emphasis on improving vocational education and job skills (Alam, 2015).

Many studies indicate that vocational training institutes in Pakistan produce graduates possessing poor work-related competence skills 
(Aggarwal, 2013; Dean, 2007; Javied \& Hyder, 2009; Khan, 2009; Mirza, Jaffri, \& Hashmi, 2014; Nabi, 2013; Park, 2005; Saigol, 2014; Shah, Rahman, Ajmal, \& Hamidullah, 2011; Uzair-ul-Hassan \& Noreen, 2013). Due to poor skills training, jobs in the local and international markets are scarce for graduates of Pakistani vocational institutes (Ansari \& Wu, 2013; Kazmi, 2007). A few studies have associated this poor performance to poor linkage between vocational training institutes, industry and the community (Amjad, ul Haque, \& Colclough, 2005; Shah et al., 2011). Additionally, compared to many developed countries, the system of vocational education in Pakistan is highly characterized by low enrolment, high dropouts, inferior quality of teachers, wide gender disparity, and low budgetary allocations (Aggarwal, 2013). Other researchers have pointed accusing fingers at the loophole in vocational training institutes which makes them unable to support economic growth and needs of the job market (Faridi, Malik, \& Ahmad, 2010). Khilji, Kakar, \& Subhan (2012) posited that the vocational training institutes of Pakistan will not be able to support high economic growth and sharp demands of the current global and local markets because of the low skills training of its graduates. This situation necessitates an urgent response from the vocational training institutions to bring about the desired change (Hogstedt, Lundgren, Moberg, Pettersson, \& Agren, 2007). Hence, the system of vocational education needs a fundamental review and restructuring (Ul-Haq \& Haq, 1998). Realizing the poor performance of Pakistani vocational education graduates, the Punjab Vocational Training Council (PVTC) took a pioneering step to introduce the service-learning course in all its vocational training institutes. The main purpose of including the service-learning course in the curriculum is to engage students in solving social problems in the community and to produce skilled, active and civically responsible graduates. It also aims to enable the students to play leadership roles, and develop teamwork and communication skills (PVTC, 2014).

\section{Service-learning Integration}

The justifications for the integration of the service-learning course in the vocational training institute curriculum are as follows: First, service-learning is considered a critical pedagogy for encouraging students' civic engagement through community service participation (O’Connor, 2006; Said, Ahmad, Hassan, \& Awang, 2015). Second, 
service-learning has been identified as one of the top high-impact teaching and learning practices for effectively connecting academic content with real-life experiences (Jerome, 2012). Third, many educational institutions around the world have embraced servicelearning as a teaching and learning approach (Butin, 2010; Lieberman, 2014). This innovative pedagogy is considered effective in preparing the young for workplace and civic responsibilities (Brown, 2015; Lambright, 2008; Said, Ahmad, Mansor, \& Awang, 2015). Fourth, it is believed that the service-learning activities (also known as service-learning projects) can promote different academic outcomes in students, including civic development and teamwork skills development (Denby, 2008; Falk, 2012; Phillips, 2011).

The service-learning course at the Pakistani vocational training institutions is implemented as a compulsory course. This means that all graduating students are required to register for it. The duration of the service-learning course is 50 hours, comprising 10 hours of actual class work and 40 hours of field work to serve the society. The marks allocated for this course followed the following criteria: $10 \%$ attendance, $10 \%$ unscheduled quizzes, $50 \%$ field work and $30 \%$ presentation of field work by the students (PVTC, 2014). The course implementation is closely supervised by selected and qualified teachers throughout the semester. The management of the institutions appoints the teachers and provides the direction and guidelines for designing, planning and implementing the service-learning course and projects. Based on this guideline, the students and teachers are free to select and meet the community of their choice, and finally develop the service-learning projects. The service-learning projects often preferred and selected by students and teachers include tutoring, mentoring, healthcare, hospital service, cleanliness, and volunteering (PVTC, 2014).

The service-learning projects are planned, designed and implemented by the students after identifying certain needs of the targeted community. While in the community, the students are closely guided by their teachers, and they are required to discuss the service experience, its importance and applications. Upon completion of the service-learning projects, the students are generally required to write reflective notes or reports on the experience to be submitted to their teachers. The service-learning experience is celebrated later in the classroom, followed by a question and answer session. The 
experience is also displayed inside or outside the classroom in the forms of pictures, notes or reports, and reflections (PVTC, 2014).

\section{Statement of the Problem}

The literature on service-learning research instrumentation is rather comprehensive (Daniel, 2013; Eyler \& Giles, 1999; GershensonGates, 2012; Lu \& Lambright, 2010; Phillips, 2011), but unfortunately its focus has been mainly on the outcomes of servicelearning in the general education field. The instruments employed in those studies do not measure factors influencing service-learning outcomes, specifically involving vocational education. Additionally, those instruments have been designed and developed in the context of the developed world. No instrument was available in the existing literature that measured service-learning outcomes, especially in the context of Pakistan which is a developing country with a unique cultural, social and geographical location. Hence, there was a clear need to develop an instrument for exploring service-learning outcomes in the context of Pakistani vocational education. This study theoretically contributes to this gap in the current servicelearning literature.

Although the service-learning course has been included in all vocational training institutes in Pakistan with the aim of producing graduates who have effective jobs skills and work-related skills, little is known about the learning outcomes resulting from participating in the course. Additionally, the existing service-learning research has mostly focused on exploring students' perspectives of their service-learning outcomes in the general education field. To date, little work exists that have investigated teachers' perspectives of service-learning outcomes. This study fills this gap by exploring perspectives of teachers in the context of vocational education in a developing country. This study is relevant as teachers are ultimately responsible for implementing and institutionalizing the servicelearning activity (Bringle \& Hatcher, 1995; Butin, 2010; Jacoby, 2013; Blakey, Theriot, Cazzell, \& Sattler, 2015).

\section{Purpose of the Study}

This quantitative study explored the perspectives of teachers on outcomes of service-learning participation in the context of vocational training institutes of Pakistan. 


\section{METHODOLOGY}

A cross sectional survey design was used to conduct this study. To measure service-learning participation outcomes in vocational training institutes of Pakistan, a self-developed survey questionnaire called Service-Learning Outcomes Scale (SLOS) was employed. Since this study explored outcomes resulting from participation in the service-learning course, the survey questionnaire wass considered a suitable instrument for primary data collection from the participants (Field, 2005). For this purpose, the scale development frameworks of DeVellis (2012), Creswell and Plano Clark (2011), and Tudor (2013) were utilized for the development of the instrument.

\section{Instrument Development}

As the first step in developing the instrument, a vast amount of literature on outcomes of service-learning was reviewed (e.g., Ahmad, Said, Mansor, Mokhtar, \& Ghani, 2014; Billig \& Eyler, 2003; Bringle \& Hatcher, 1995; Birdwell et al., 2013; Brown, 2015; Burns \& Stokamer, 2011; Butin, 2010; Calvert \& Kurji, 2012; Couse \& Russo, 2006; Daly, Baker, \& Williams, 2014; Daniel, 2013; Deba, Jabor, Buntat, \& Musta'mal, 2014; Deba, Jabor, Sukri Saud, \& Buntat, 2015; Deeley, 2010; Denby, 2008; Eyler \& Giles, 1999; Eyler et al., 1997; Felten \& Clayton, 2011; Ferrari \& Chapman, 2014; Furco, 2010; Gershenson-Gates, 2012; Gerstenblatt \& Gilbert, 2014; Greenman, 2014; Jacoby, 2003; Jacoby, 2013; Jerome, 2012; Lu \& Lambright, 2010; O’Grady, 2014; Said, Ahmad, Hassan, \& Awang, 2015; Said, Ahmad, Mansor, \& Awang, 2015; Waterman, 2014). Afterwards important significant statements were collected, and out of these statements, three themes were extracted: content knowledge, interpersonal skills, and volunteering attitude. Based on the three themes, 18 item questions were generated using the most frequently reported statements related to these themes. The process of item generation for the instrument consisted of converting themes to quotes and quotes to item questions. In keeping with the suggestion of scholars on developing an instrument, leading and loaded item questions were avoided (Teddlie \& Tashakkori, 2003). The item questions developed were clear, simple and free from overlaps. Unclear and double-barreled questions were avoided (Creswell \& Plano Clark, 2011). For item question development, researchers have suggested that three to five item questions per scale may provide adequate internal consistency (Hinkin, Tracey, \& Enz, 1997). 
The instrument questions were written as statements with a fivepoint Likert scale. The Likert scale was used to indicate the level of agreement to the statement, from Strongly Agree, Agree, Undecided, Disagree and Strongly Disagree. Each category was coded with values starting from ' 5 ' for Strongly Agree to ' 1 ' for Strongly Disagree. This type of scale has the quality to generate a higher reliability coefficient than other scales (Hayes, Perander, Smecko, \& Trask, 1998). Likert scales also allowed each respondent to express his or her opinions in varying degrees. Additionally, it allowed the researchers to examine the percentages of different responses for each measure.

\section{Definition of the Variables}

Each theme of the instrument consisted of more than three item questions: Content knowledge (6 item questions), interpersonal skills (5 item questions), and volunteering attitude ( 7 item questions). The term content knowledge referred to knowledge of the subject matter and its requirements, as well as the community the students served during the service-learning; interpersonal skills or people skills alluded to the behaviours and traits that students relied on when communicating and building relationships with others, resulting from participating in service-learning; whereas volunteering attitude referred to showing interest in working in groups and volunteering to the community, resulting from service-learning participation.

\section{Validation}

The newly drafted instrument was shown to three experts in the field of service-learning and education for content and face-value validity checking. All the experts possessed a PhD in Education. One expert was an Associate Professor in a university in the USA, while the other two were faculty members from local universities in Pakistan. All three experts had experience teaching and implementing servicelearning in their institutions for more than a decade. They were asked to examine each item question separately to determine its clarity and relevancy. The instrument was also shown to five teachers to seek their understanding. In light of their feedback, the item questions were refined.

The reliability of the questionnaire was established through internal consistency using the Cronbach alpha technique. Hinkin (1995) 
suggested that Cronbach alpha is the best estimate of internal consistency of item questions in an instrument. This technique was used along with the 'Corrected Item Total Correlation' to determine the reliability of the instrument. In this study, a Cronbach alpha value of .70 was taken as an acceptable threshold level (Phillips, 2011; Shiarella, McCarthy, \& Tucker, 2000). Based on Shiarella et al. (2000), item questions below .40 were deleted. For this purpose, the Cronbach alpha test was run many times for each scale. Each time, the item questions with poor Cronbach alpha value, as shown in the 'Corrected Item Total Correlation' were deleted. The final instrument for this study consisted of 11 items and three subscales: content knowledge (4 item questions), interpersonal skills (4 item questions) and volunteering attitude (3 item questions). Using the Statistical Package for Social Science (SPSS), the reliability of the questionnaire was found to be .80, which was an acceptable level for conducting a survey.

\section{Data Collection}

The data were collected from teachers of vocational training institutes located in three zones of Punjab-- North, South and Central Punjab province, who participated in the service-learning courses. As this study used exploratory factor analysis for data analysis, the number of survey respondents must be large enough to represent the population (Gay \& Airasian, 2003). Since each vocational training institute consisted of between 22-30 teachers who participated in the service-learning course each year, and this study needed a sample size of 300 to 500 for factor analysis, five vocational training institutes from each zone were randomly selected. To achieve this randomization, the names of all the vocational training institutes from each zone were written on separate pieces of papers. Then, one by one the names of the institute were drawn for each zone.

The principals of the selected institutes were contacted, and permission was sought for data collection. Then, the principals were requested to contact all teachers who participated in the servicelearning courses implemented in the year 2015-2016. Accordingly, the principals were requested to gather their respective teachers at the appointed place, time and date. During the introduction session, the teachers were briefed about the objectives of the research and they were asked for consent to participate in the research. They 
were informed that they could decline the invitation to participate or withdraw from participating in the research at any time. They were ensured that their names or identifiable features would not be disclosed. The questionnaires were collected on the spot.

\section{Participants}

Table 1

Demographic Data of Respondents

\begin{tabular}{llcc}
\hline Respondents & \multicolumn{1}{c}{ Gender } & Frequency & Percentage \\
\hline \multirow{2}{*}{ Teachers } & Male & 212 & $67 \%$ \\
& Female & 103 & $34 \%$ \\
\hline Total & & 315 & $100 \%$ \\
\hline
\end{tabular}

Table 1 indicates the number of teachers involved in this study. Of the total number of 315 teachers, $212(67 \%)$ were male and 103 $(34 \%)$ were female; the number of male teachers was almost double that of the female teachers.

\section{RESULTS}

To address the research question stated above, EFA was conducted. This approach is widely used in the social science literature as an explorative technique (e.g., Islam, 2012; Manzoor, 2013). Before conducting the factor analysis, the Kaiser-Meyer-Olkin (KMO) and Bartlett's Test of sphericity were checked as pre-conditions to assess the suitability of data for analysis. Generally, a KMO of above 0.50 is considered suitable and the Bartlett's Test of sphericity is required to be significant at $(\mathrm{p}<.05)$ for conducting EFA.

\section{Table 2}

KMO and Bartlett's Test of Sphericity for SLOS

\begin{tabular}{|c|c|c|}
\hline $\begin{array}{l}\text { Kaiser-Meyer-Olkin (KMO) } \\
\text { Measure of Sampling Adequacy }\end{array}$ & & .938 \\
\hline Approx. Chi-Square & & 2659.850 \\
\hline Bartlett's Test of Sphericity & Sig. & .000 \\
\hline
\end{tabular}


As shown in Table 2, the KMO was .938 and the Bartlett's Test of Sphericity was significant at .000 , which provided the evidence for sample adequacy to proceed with the current factor analysis (Fiedel, 2005). The Principal Component Analysis (PCA) technique was used as an explorative technique to evaluate the three-factor model. The PCA technique extracted a three-factor model based on 11 items. These factors were the major outcomes of service-learning course participation in Pakistani vocational training institutes. Based on the PCA technique, three factors were retained: factor 1-- content knowledge, factor 2-- interpersonal skills, and factor3-volunteering attitude. Content knowledge referred to the subject matter knowledge of students, interpersonal skills referred the ability of students to interact with others and observe social skills, while volunteering attitude referred to the ability to give services to the community without any personal gains.

Table 3

Common Variance Extraction

\begin{tabular}{lccccc}
\hline \multicolumn{1}{c}{ Factors } & $\begin{array}{c}\text { Common } \\
\text { variation }\end{array}$ & Cumulative & KMO & $\begin{array}{c}\text { Chi- } \\
\text { Square }\end{array}$ & Sig. \\
\hline $\begin{array}{l}\text { Content } \\
\text { Knowledge }\end{array}$ & 64.846 & 64.846 & & & \\
$\begin{array}{l}\text { Interpersonal } \\
\text { Skills }\end{array}$ & 6.153 & 71.000 & .938 & 2659.850 & 0.000 \\
$\begin{array}{l}\text { Volunteering } \\
\text { Attitude }\end{array}$ & 5.416 & 76.415 & & & \\
\hline
\end{tabular}

Table 3 indicates the factorisation of the 3 components. The total variance of the scale is 76.415 based on 11 items. The first component (content knowledge) shared 64.846 of the common variation, the second factor (interpersonal skills) shared 6.153 in the common variation, and the third factor (volunteering attitude) shared 5.416 of the common variation respectively.

Table 4 presents the item loadings for the outcomes of servicelearning participation in vocational training institutes of Pakistan. The mean scores for all items in the 3 factors (interpersonal skills, content knowledge, and volunteering attitude) were very high. This shows that most of the respondents strongly viewed them as outcomes of service-learning course participation. 
Table 4

Item Loading for Service-Learning Participation Outcomes

\begin{tabular}{|c|c|c|c|c|}
\hline Factor & Item & $\begin{array}{c}\text { Factor } \\
\text { Loading }\end{array}$ & Mean & SD \\
\hline \multirow{4}{*}{$\begin{array}{l}\text { Interpersonal } \\
\text { Skills }\end{array}$} & $\begin{array}{l}\text { Q1 Students easily make } \\
\text { friends. }\end{array}$ & 0.75 & 4.31 & .70 \\
\hline & $\begin{array}{l}\text { Q2 Students work with diverse } \\
\text { groups. }\end{array}$ & 0.75 & 4.31 & .70 \\
\hline & $\begin{array}{l}\text { Q3 Students can effectively } \\
\text { communicate with others. }\end{array}$ & 0.92 & 4.36 & .69 \\
\hline & $\begin{array}{l}\text { Q4 Students collaborate with } \\
\text { community members. }\end{array}$ & 0.88 & 4.32 & .68 \\
\hline \multirow{4}{*}{$\begin{array}{l}\text { Content } \\
\text { Knowledge }\end{array}$} & $\begin{array}{l}\text { Q5 Demonstrate better } \\
\text { preparation for examination. }\end{array}$ & 0.76 & 4.25 & .77 \\
\hline & $\begin{array}{l}\text { Q6 Developed better } \\
\text { understanding of civic } \\
\text { responsibilities. }\end{array}$ & 0.78 & 4.30 & .73 \\
\hline & $\begin{array}{l}\text { Q7 Knowledge of course } \\
\text { content increased. }\end{array}$ & 0.81 & 4.24 & .75 \\
\hline & Q8 Know how to lead groups. & 0.71 & 4.25 & .72 \\
\hline \multirow{3}{*}{$\begin{array}{l}\text { Volunteering } \\
\text { Attitude }\end{array}$} & $\begin{array}{l}\text { Q9 Show interest to help the } \\
\text { community. }\end{array}$ & 0.84 & 4.30 & .70 \\
\hline & $\begin{array}{l}\text { Q10 Demonstrate willingness } \\
\text { to work in groups. }\end{array}$ & 0.84 & 4.34 & .67 \\
\hline & $\begin{array}{l}\text { Q11 Show willingness to } \\
\text { volunteer for community. }\end{array}$ & 0.86 & 4.42 & .66 \\
\hline
\end{tabular}

\section{DISCUSSION}

This study explored the perspectives of teachers on service-learning participation outcomes in the context of Pakistani vocational education. The study found that content knowledge was the most important outcome of service-learning course participation in vocational training institutes of Pakistan. The inclusion of servicelearning courses in the curriculum helped students to apply their classroom knowledge in a practical setting, which eventually enhanced their understanding of the content materials. During the service-learning project implementation, the students underwent 
training which refined their knowledge. They gained new skills when they worked in the community alongside others (Ngai, Cheung, Ngai, \& Chan, 2010). This finding supports previous literature on service-learning courses conducted in developed countries. For example, in their respective studies, Stewart (2012) and Bowen (2010) found that the inclusion of a service-learning course increased students' professional skills and civic abilities and knowledge about community issues. Kovarik (2010) and more recently, Daly et al. (2014) indicated that participation in service-learning courses provided wider learning opportunities for students. By participating in service-learning, students would come across different people and issues in the community. The course also permits them to apply their ideas in new situations, which would enhance their knowledge.

Previous experiences have indicated that service-learning is an effective approach for education. For example, service-learning is an activity that focuses on meeting community needs. It helps achieve key academic goals by combining service with learning. The service activity incorporates students' reflection on their service experiences by connecting specific academic goals with the service activity. Students find wider opportunities for participation in the practical learning environment. This experience meets community needs on one hand and students' learning on the other. The service experience is coordinated collaboratively between the educational institutions and the community. Waterman (2014) highlighted that service-learning provides students with structured time to think, talk and write about what they do and their experience undergoing the learning activity. This experience enhances what they learn in the classroom by extending it into the community. This helps in fostering among them a sense of volunteerism and care towards others.

The application of service-learning courses help institutions to develop service-minded graduates (Burns \& Stokamer, 2011; Falk, 2012; Jacoby, 2013) and contributes towards development of students in the work domain by enhancing their knowledge and work-related skills (Eyler \& Giles, 1999; Falk, 2012; Furco, 2002; Phillips, 2011). Students who participate in service-learning courses find better chances of employment. Many studies have shown that service-learning is a useful method to equip the graduates with coveted work-related skills such as teamwork, communication skills, and decision-making and problem solving skills (Ansari \& 
Wu, 2013; Dean, 2005; Hina, Ajmal, Rahman, \& Jumani,. 2011; Keller, Parker, \& Chan, 2011). These skills are considered very important employability skills in the current job market. Compared with other traditional methods of education, service-learning makes it really possible to develop these skills in the students and prepare them for the world of work (Calvert \& Kurji, 2012; Greenman, 2014; Vandzinskaite, Mazeikiene, \& Ruskus, 2010). Engagement in problem solving and working cooperatively in teams during servicelearning build in these students, the skills that are needed in today's workplace. In the current job market, employers and organizations are increasingly looking for graduates who have effective communication skills, and problem-solving vision. Service-learning addresses these needs by promoting pre-employment skills and job readiness in students who participate in service activities (Daniel, 2013). Based on this finding, it can be argued that service-learning courses employ a learning approach that encourages active learning and enhances students' first-hand knowledge by applying their previous knowledge in real-life situations.

The study also found that interpersonal skills development of students is the second most important outcome of service-learning course participation in vocational training institutes of Pakistan. This finding also supports the existing body of knowledge. For example, Eyler and Giles (1999) discovered that students participating in service-learning showed better interpersonal skills. Similarly, Deba et al. (2014), Deba et al. (2015), and Lambright and Lu (2010) found that as a community-based educational approach, the inclusion of service-learning course provides practical opportunities for students to interact, instilling in them the ability to easily make friends. This interaction promotes and enhances their interpersonal skills. Phillips (2011) noted that the inclusion of a service-learning course gives more transparent opportunities to students to practice outside the traditional boundary of classroom walls and this subsequently leads to more meaningful collaboration with the community. This opportunity enhances their courage and self-esteem, and they consider themselves worthy of providing help to others (Hurd, 2008).

The service-learning course provides students with the opportunity to communicate effectively with diverse groups of peoples in the community in a real-life context that develops their sense of civic 
responsibility (Levesque-Bristol, Knapp, \& Fisher, 2010). Working with community members further enhances their teamwork and interpersonal skills. They also enrich themselves with the experience of working with diverse groups of people. In addition, exploring and developing ways of contributing towards their communities helps them to better understand their roles. All these experiences eventually enhance their confidence and commitment to public service (Roehlkepartain, 2009).

The finding of this study with regard to the second important outcome of service-learning course participation. i.e., interpersonal skills development, offers a new paradigm for education in Pakistan that may challenge established views in Pakistani education. Pakistani classrooms are generally perceived as being oriented towards teacher dominance whereby students are seldom provided with the chance to speak and share their ideas, i.e., a culture of silence and obedience (Dean, 2005). These have always been considered essential principles for socialisation of students in a Pakistani classroom. The finding of this study is thus unique as it indicates the positive impact of applying service-learning as a teaching and learning approach on the interpersonal skills development of students. Based on this finding, it can be argued that participation in the service-learning course in Pakistani vocational training institutes enhances the interpersonal skills of students. This significant finding may now change the landscape of education in Pakistan.

The study found volunteering attitude to be the third important outcome of service-learning course participation. This finding further supports the results of previous studies. For example, Butin (2010) reported that students who took part in service-learning projects tended to develop positive attitudes towards community service, i.e., they showed positive commitment towards future community participation. In a more recent study, Blakey et al. (2015) observed that students who were provided with the opportunity to interact with the community during the service-learning activity became empathetic and supportive towards other people. The students examined the different problems of people in the community and showed willingness to solve them. This interaction between the students and the community during the service-learning project developed in the students the feeling of volunteerism. They even discharged their services to the community in their free time. 
In the context of Pakistani education, the finding on developing a volunteering attitude is unique and interesting. According to Dean (2007), Pakistani education has always traditionally been geared towards preparing students for grades and examination. There is limited mechanism to uplift the creative and social abilities of students through critical thinking and active participation in learning. As a result, students work on memorising the content rather than display a participatory approach towards learning, which would enhance other faculties such as critical thinking, questioning or volunteering. These aspects have been overlooked by educators in the context of the classroom. Hina et al. (2011) concur with the views of Dean (2005) and further elaborate that students in Pakistani classrooms lack abilities in civic participation and volunteerism. Moreover, they are encouraged to rote learn course content and prepare for good grades in examinations. There are efforts on the part of educators and planners to involve students as participants and stakeholders. Based on this finding, it can be argued that the inclusion of the service-learning course in vocational training institutes has positively contributed towards developing the volunteering attitudes of students. This finding can perhaps ignite motivation among educators, planners, and administrators of other educational institutions to adopt service-learning as a teaching and learning methodology.

\section{Suggestions for Future Studies}

This study used a quantitative methodology to evaluate factors influencing service-learning implementation and outcomes of service-learning participation in Pakistani vocational training institutes, from the perspectives of teachers. It is recommended that future research be conducted using mixed methodology to explore the same issues in other contexts where service-learning is implemented. This will provide a deeper and broader understanding of the issues involved, and will also cross validate the results of the current study.

This study exclusively explored the perspectives of teachers regarding the contributions of service-learning in vocational education institutes of Pakistan. It is recommended that future research in the Pakistani context could explore the perspectives of the community on factors influencing service-learning implementation in vocational 
training institutes. Such a study will provide a clearer picture of the issues involved from the community's point of view, which could lead to new insights and understanding about service-learning implementation and its outcomes, its benefits and challenges. It will also open up new avenues and vistas for future research in the field of service-learning in the context of vocational education and general education.

\section{ACKNOWLEDGEMENT}

This study is sponsored by the Ministry of Higher Education (MOHE) and Universiti Teknologi Malaysia (UTM) with the ERGS Vote No. 4L118.

\section{REFERENCES}

Abdul Karim, A. M., Abdullah, N., Abdul Rahman, A. M., Noah, S. M., Wan Jaafar, W. M., Othman, J., Said, H. (2012). A nationwide comparative study between private and public university students' soft skills. Asia Pacific Education Review, 13(3), 541-548.

Aggarwal, A. (2013). Lessons learnt from informal apprenticeship initiatives in Southern and Eastern Africa. The International Conference on Apprenticeship. April 23-24, Johannesburg, South Africa.

Ahmad, I., \& Said, H. (2016). Application of Astin's theory of students' involvement in service-learning at higher education. Man in India, 96(1-2), 231-245.

Ahmad, I., Said, H., Mansor, S. S. S., Mokhtar, M., \& Ghani, F. A. (2014). Role of reflection in moderating the relationship between service-learning and civic development. Review of European Studies, 6(3), 74-80.

Alam, N. (2015). The role of technical vocational education and training in human development: Pakistan as a reference point. European Scientific Journal, 11(10), 35-50.

Althof, W., \& Berkowitz, M. W. (2006). Moral education and character education: Their relationship and roles in citizenship education. Journal of Moral Education, 35(4), 495-518. 
Amjad, R., ul Haque, N., \& Colclough, C. (2005). Skills and competitiveness: Can Pakistan break out of the low-level skills trap? The Pakistan Development Review, 5(2), 387-409.

Ansari, B., \& Wu, X. (2013). Development of Pakistan's technical and vocational edcuation and training (TVET): An analsysis of skilling Pakistan reforms. Journal of Technical Education and Training, 5(2), 12-24.

Assendelft, L. V. (2008). "City council meetings are cool": Increasing student civic engagement through service learning. Journal of Political Science Education, 4(1), 86-97.

Astin, A. W., \& Sax, L. J. (1998). How undergraduates are affected by service participation. Journal of College Student Development, 39(3), 251-263.

Baldwin, S. C., Buchanan, A. M., \& Rudisill, M. E. (2007). What teacher candidates learned about diversity, social justice, and themselves from service-learning experiences. Journal of Teacher Education, 58(4), 315-327.

Billig, S., Root, S., \& Jesse, D. (2005). The impact of participation in service-learning on high school students' civic engagement. CIRCLE Working Paper 33. Center for Information and Research on Civic Learning and Engagement (CIRCLE), University of Maryland.

Billig, S. H. (2012). Service-learning. In J. Hattie \& E. M. Anderman (Eds.), International guide to student achievement, 158-161. New York, NY: Routledge.

Billig, S. H., \& Eyler, J. (2003). The state of service-learning and service-learning research. In S. H. Billig \& J. Eyler (Eds.), Deconstructing service-learning: Research exploring context, participation, and impacts. A volume in advances in servicelearning research, 253-264. Greenwich, UK: Information Age.

Birdwell, J., Scott, R., \& Horley, E. (2013). Active citizenship, education and service learning. Education, Citizenship and Social Justice, 8(2), 185-199.

Blakey, J. M., Theriot, S., Cazzell, M., \& Sattler, M. (2015). Is service-learning worth it? A mixed-methods study of faculty's service-learning experiences. The International Journal of Research on Service-Learning and Community Engagement, 3(1), 13-26.

Blouin, D. D., \& Perry, E. M. (2009). Whom does service learning really serve? Community-based organizations' perspectives on service learning. Teaching Sociology, 37(2), 120-135. 
Bowen, G. (2010). Service learning in the scholarship of teaching and learning: Effective practices. International Journal for the Scholarship of Teaching and Learning, 4(2), 18-34.

Bringle, R. G., \& Hatcher, J. A. (1995). A service-learning curriculum for faculty. Michigan Journal of Community Service Learning, 2(1), 112-122.

Brown, E. (2015). The effects of service-learning courses on students participating in service projects (Unpublished masters thesis). Goucher College, USA.

Burns, H., \& Stokamer, S. (2011). Cultivating student leaders through service learning. Proceedings of Annual Conference of Oregon Women in Higher Education, Portland, Oregon, January 28, 2011.

Butin, D. W. (2010). Conceptualizing service-learning. In D. W. Butin (Eds.), Service-learning in theory and practice: The future of community engagement in higher education, 3-22. New York, NY: Palgrave Macmillan.

Calvert, V., \& Kurji, R. (2012). Service-learning in a managerial accounting course: Developing the soft skills. American Journal of Economics and Business Administration, 4(1), 5-12.

Chappell, C. (2003). Researching vocational education and training: Where to from here? Journal of Vocational Education and Training, 55(1), 21-32.

Couse, L. J., \& Russo, H. L. (2006). Servicellearning: Mentoring leadership skills in the experienced teacher. Mentoring \& Tutoring, 14(1), 33-48.

Creswell, J. W., \& Plano Clark, V. L. (2011). Designing and conducting mixed methods research $\left(2^{\text {nd }}\right.$ ed.). Thousand Oaks, CA: Sage.

Crossman, J. M., \& Kite, S. L. (2007). Their perspectives: ESL students' reflections on collaborative community service learning. Business Communication Quarterly, 70(2), 147165.

Daly, D. M., Baker, S., \& Williams, S. J. (2014). Prospects for integrating service learning into short-term international study. Journal of Education and Learning, 3(1), 16-24.

Daniel, C. A. (2013). The impact of service-learning on community involvement attitude in career and technical education students (Unpublished doctoral dissertation). Liberty University, USA. 
Dean, B. L. (2005). Citizenship education in Pakistani schools: Problems and possibilities. International Journal of Citizenship and Teacher Education, 1(2), 35-44.

Dean, B. L. (2007). The state of civic education in Pakistan. Civil society programme, Aga Khan foundation Pakistan, Islamabad: AKU-IED. Retrieved from http://www.akdn. org/ civil_society.asp.

Deba, A. A., Jabor, M. K., Buntat, Y., \& Musta'mal, A. H. (2014). Potential of service-learning on students' interpersonal skills development in technical and vocational education. Asian Social Science, 10(21), 1-9.

Deba, A. A., Jabor, M. K., Sukri Saud, M., \& Buntat, Y. (2015). Dilemmas affecting the integration of service-learning in technical and vocational education in Nigeria. Asian Social Science, 11(10), 1-11.

Deeley, S. J. (2010). Service-learning: Thinking outside the box. Active Learning in Higher Education, 11(1), 43-53.

Denby, R. A. (2008). The impact of servcie-learning on students' sense of civic responsbility (Unpublished masters thesis). The University of Western Ontario, Canada.

DeVellis, R. F. (2012). Scale development: Theory and applications ( $3^{\text {rd }}$ ed.). Thousand Oaks, CA: Sage.

Ehrlich, T. (1998). Reinventing John Dewey's "pedagogy as a university discipline". The Elementary School Journal, 98(5), 489-509.

Einfeld, A., \& Collins, D. (2008). The relationships between servicelearning, social justice, multicultural competence, and civic engagement. Journal of College Student Development, 49(2), 95-109.

Eyler, J., \& Giles Jr, D. E. (1999). Where's the learning in servicelearning? San Francisco, CA: Jossey-Bass.

Eyler, J., Giles Jr, D. E., \& Braxton, J. (1997). The impact of servicelearning on college students. Michigan Journal of Community Service Learning, 4, 5-15.

Falk, A. (2012). Enhancing the team experience in service learning courses. Journal for Civic Commitment, 2(18), 1-12.

Faridi, M. Z., Malik, S., \& Ahmad, R. I. (2010). Impact of education and health on employment in Pakistan: A case study. European Journal of Economics, Finance and Administrative Sciences, 6(18), 58-68.

Felten, P., \& Clayton, P. H. (2011). Servicellearning. New Directions for Teaching and Learning, 2011(128), 75-84. 
Ferrari, J. R., \& Chapman, J. G. (2014). Educating students to make a difference: Community-based service learning. New York, NY: Routledge.

Fiedel, E. (2005). Interpretation of factor analysis using SPSS. Retrieved from https://www.projectguru.in/publications/ interpretation-of-factor-analysis-using-spss/

Field, A. (2005). Discovering statistics using SPSS (2 $2^{\text {nd }}$ ed.). London: Sage.

Furco, A. (2002). Is service-learning really better than community service? A study of high school service program outcomes. In A. Furco \& S. H. Billig (Eds.), Service-learning: The essence of pedagogy (p. 23-50). Greenwich, CT: Information Age Publishing.

Furco, A. (2010). The community as a resource for learning: An analysis of academic service-learning in primary and secondary education. In H. Dumont, D. Istance, and F. Benavides (Eds.), The Nature of Learning: Using Research to Inspire Practice, 227-249. Paris: OECD Publishing.

Gay, L. R., \& Airasian, P. (2003). Educational research: Competencies for analysis and applications ( $7^{\text {th }}$ ed.). Upper Saddle River, NJ: Merril Prentice Hall.

Gershenson-Gates, R. (2012). The impact of service-learning on college students' civic development and sense of self-efficacy (Unpublished doctoral dissertation). College of Science and Health, DePaul University, USA.

Gerstenblatt, P., \& Gilbert, D. J. (2014). Framing service learning in social work: An interdisciplinary elective course embedded within a university-community partnership. Social Work Education: The International Journal, 33(8), 1037-1053.

Giles, D. E., \& Eyler, J. (1994). The theoretical roots of servicelearning in John Dewey: Toward a theory of service-learning. Michigan Journal of Community Service Learning, 1(1), 7785.

Greenman, A. (2014). The effects of experiential, service-learning summer learning programs on youth outcomes (Unpublished doctoral dissertation). Northeastern University, USA.

Hayes, B. E., Perander, J., Smecko, T., \& Trask, J. (1998). Measuring perceptions of workplace safety: Development and validation of the work safety scale. Journal of Safety Research, 29(3), 145-161. 
Hina, K. B., Ajmal, M., Rahman, F., \& Jumani, N. B. (2011). State of citizenship education: A case study from Pakistan. International Journal of Humanities and Social Science, 1(2), 37-43.

Hinkin, T. R. (1995). A review of scale development practices in the study of organizations. Journal of Management, 21(5), 967988.

Hinkin, T. R., Tracey, J. B., \& Enz, C. A. (1997). Scale construction: Developing reliable and valid measurement instruments. Journal of Hospitality \& Tourism Research, 21(1), 100-120.

Hogstedt, C., Lundgren, B., Moberg, H., Pettersson, B., \& Agren, G. (2007). Background to the new Swedish public health policy. Scandivanian Journal of Public Health, 32(64), 6-17.

Hurd, C. A. (2008). Is service-learning effective?: A look at current research. Service Learning: Perspectives and Applications, $1-11$.

Idris, R., Ariffin, S. R., \& Mohd Ishak, N. (2009). Pengaruh kemahiran generik dalam kemahiran pemikiran kritikal, penyelesaian masalah dan komunikasi pelajar Universiti Kebangsaan Malaysia (UKM). Malaysian Journal of Learning and Instruction, 6, 103-140.

Islam, S. (2012). An empirical analysis of factors inspiring students for admission in distance education program at Bangladesh open university: A case study. Pakistan Journal of Education, 29(2), 12-21.

Jacobson, J., Oravecz, L., Falk, A., \& Osteen, P. (2011). Proximate outcomes of service-learning among family studies undergraduates. Family Science Review, 16(1), 22-33.

Jacoby, B. (2003). Fundamentals of service-learning partnerships. In B. Jacoby \& Associates (Eds.), Building partnerships for service-learning, 1-19. San Francisco, CA: Jossey-Bass.

Jacoby, B. (2013). Democratic dilemmas of teaching servicelearning: Curricular strategies for success. Journal of College Student Development, 54(3), 336-338.

Javied, Z., \& Hyder, A. (2009). Impact of training on earnings: Evidence from Pakistani industries. Asian Social Science, 5(11), 76-84.

Jernstedt, G. C., Olm-Shipman, C., \& Reed, V. (2003). Teaching children about health, part II: The effect of an academiccommunity partnership on medical students' communication skills. Education for Health, 16(3), 339-347. 
Jerome, L. (2012). Service learning and active citizenship education in England. Education, Citizenship and Social Justice, 7(1), 59-70.

Kahne, J., \& Westheimer, J. (2006). The limits of political efficacy: Educating citizens for a democratic society. PS: Political Science \& Politics, 39(2), 289-296.

Kazmi, S. W. (2007). Vocational education and skills development: A case of Pakistan. SAARC Journal of Human Resource Development, 3(1), 24-35

Keller, S., Parker, C. M., \& Chan, C. (2011). Employability skills: Student perceptions of an IS final year capstone subject. Innovation in Teaching and Learning in Information and Computer Sciences, 10(2), 4-15.

Kemal, A. R. (2005). Skill development in Pakistan. The Pakistan Development Review, 44(4), 349-357.

Khan, S. H. (2009). Making people employable: Reforming secondary education in Pakistan. The Pakistan Development Review, 23(3), 603-617.

Khilji, B. A., Kakar, Z. K., \& Subhan, S. (2012). Impact of vocational training and skill development on economic growth in Pakistan. World Applied Science Journal, 17(10), 12-30.

Kincheloe, J. L. (1999). How do we tell the workers? The socioeconomic foundations of work and vocational education. New York, NY: Routledge.

Kolb, A. Y. (2005). The Kolb learning style inventory-version 3.1, technical specifications. Boston, MA: Hay Group.

Kolb, D. A., Boyatzis, R. E., \& Mainemelis, C. (2001). Experiential learning theory: Previous research and new directions. In R. J. Sternberg \& L. Zhang (Eds.), Perspectives on thinking, learning, and cognitive styles, 227-247. Mahwah, NJ: Lawrence Erlbaum Associates.

Kovarik, M. (2010). The effect of service-learning on interdisciplinary learning and curriculum reinforcement, and its application to public school environments. International Journal for the Scholarship of Teaching and Learning, 4(1), 2-21.

Lambright, K. (2008). Lessons outside of the classroom: Examining the effectiveness of service learning projects at achieving learning objectives. Journal of Public Affairs Education, 5(3), 205-217. 
Levesque-Bristol, C., Knapp, T. D., \& Fisher, B. J. (2010). The effectiveness of service-learning: It's not always what you think. The Journal of Experiential Education, 33(3), 208-220.

Lieberman, D. (2014). The ABCDs of service-learning: Who is serving whom? Journal of Higher Education Outreach and Engagement, 18(4), 7-16.

Llenares, I. I., \& Deocaris, C. C. (2018). Measuring the impact of a community extension program in the Philippines. Malaysian Journal of Learning and Instruction, 15(1), 35-55.

Lu, Y., \& Lambright, K. T. (2010). Looking beyond the undergraduate classroom: Factors influencing service learning's effectiveness at improving graduate students' professional skills. College Teaching, 58(4), 118-126.

Manzoor, A. (2013). Factors driving business consumer adoption of broadband in Pakistan: An exploratory study. Journal of Business Studies Quarterly, 3(4), 43-51.

Melchior, A., \& Bailis, L. N. (2002). Impact of service-learning on civic attitudes and behaviors of middle and high school youth: Findings from three national evaluations. In A. Furco \& S. H. Billig (Eds.), Advances in service-learning research: Volume 1 service learning: The essence of the pedagogy, 201-222. Greenwich, CT: Information Age.

Metzger, A., \& Ferris, K. (2013). Adolescents' domain-specific judgments about different forms of civic involvement: Variations by age and gender. Journal of Adolescence, 36(3), 529-538.

Mirza, F. M., Jaffri, A. A., \& Hashmi, M. S. (2014). An assessment of industrial employment skill gaps among university graduates: In the Gujrat-Sialkot-Gujranwala industrial cluster, Pakistan. Pakistan Strategic Support Programme. Working Paper 017. Retrieved from http://www. http://pdf.usaid.gov/

Mortaki, S. (2012). The contribution of vocational education and training in the preservation and diffusion of cultural heritage in Greece: The case of the specialty guardian of museums and archaeological sites. International Journal of Humanities and Social Science, 2(24), 51-58.

Nabi, I. (2013). Two social protection programs in Pakistan. The Lahore Journal of Economics, 18(3), 283-297.

Ngai, S. S. (2006). Service-learning, personal development, and social commitment: A case study of university students in Hong Kong. Adolescence, 41(161), 165-176. 
Ngai, S. S. Y., Cheung, C. K., Ngai, N. P., \& Chan, K. B. (2010). Building reciprocal partnerships for service-learning: The experiences of Hong Kong secondary school teachers. Child \& Youth Services, 31(3-4), 170-187.

O'Connor, J. S. (2006). Civic engagement in higher education. Change: The Magazine of Higher Learning, 38(5), 52-58.

O'Grady, C. R. (2014). Integrating service learning and multicultural education: An overview. In C. R. O'Grady (Ed.), Integrating service learning and multicultural education in colleges and universities, 1-20. New York, NY: Routledge.

Park, M. (2005, September). Building human resource highways through vocational training. Paper presented at the International Seminar on Vocational Content in Mass Higher Education? Responses to the Challenges of the Labour Market and the Work-place. Bonn. Germany.

Pedler, M. (2011). Action learning in practice. New York, NY: Gower.

Phillips, J. M. (2011). Integrating service learning into the classroom: Examining the extent to which students achieve course objectives and a sense of civic responsibility by engaging in service learning (Unpublished doctoral dissertation). Edgewood College, USA. Retrieved from eric. ed.gov/?id=ED533766

Pless, N. M., Maak, T., \& Stahl, G. K. (2011). Developing responsible global leaders through international servicelearning programs: The Ulysses experience. Academy of Management Learning \& Education, 10(2), 237-260.

Punjab Vocational Training Council (PVTC) (2014). PVTC at glance. Retrieved from http://www.pvtc.gop.pk/

Robinder, K. E. (2012). Service learning as civic pedagogy: A narrative inquiry exploring the community college student experience (Unpublished $\mathrm{PhD}$ dissertation). Colorado State University, USA.

Rocheleau, J. (2004). Theoretical roots of service-learning: Progressive education and the development of citizenship. B. W. Speck and S. L. Hoppe (Eds.), Service-learning: History, theory, and issues (pp. 3-22). Westport, CT: Greenwood Publishing Group.

Roehlkepartain, E. C. (2009). Service-learning in community-based organizations: A practical guide to starting and sustaining high-quality programs. Retrieved from http://www. communityservicelearning.ca/ 
Said, H., Ahmad, I., Hassan, Z., \& Awang, Z. (2015). Servicelearning as critical pedagogy: Implications for students community awareness and citizenship development. Mediterranean Journal of Social Sciences, 6(2), 471-478

Said, H., Ahmad, I., Mansor, S. S. S., \& Awang, Z. (2015). Exploring different perspectives on limitations and promises of servicelearning as an innovative pedagogy: Review of literature. Mediterranean Journal of Social Sciences, 6(4), 311-317.

Said, H., Ahmad, I., Tahir, L. M., Ahmad, R., \& Hassan, Z. (2013). Effect of community participation on school community relations. Middle East Journal of Scientific Research, 16(3), 378-382.

Saigol, R. (2014). The making of the Pakistani citizen: Civic education and state nationalism in Pakistan. In E. Vickers \& K. Kumar (Eds.), Constructing modern Asian citizenship, 175-195. New York, NY: Routledge.

Shah, I. H., Rahman, F., Ajmal, M., \& Hamidullah, H. M. (2011). Situation analysis of technical and vocational training: A case study from Pakistan. International Journal of Academic Research, 3(1), 23-33.

Sheil, A., \& Bahk, C. (2010). Exploring the pedagogical outcomes of service learning in international public relations education. International Journal of Innovation and Learning, 7(3), 274289.

Shiarella, A. H., McCarthy, A. M., \& Tucker, M. L. (2000). Development and construct validity of scores on the community service attitudes scale. Educational and Psychological Measurement, 60(2), 286-300.

Simons, L., \& Cleary, B. (2006). The influence of service learning on students' personal and social development. College Teaching, 54(4), 307-319.

Stanton, T. K. (1987, October). Liberal arts, experiential learning and public service: Necessary ingredients for socially responsible undergraduate education. Paper presented at the 16th annual conference of the National Society for Internships and Experiential Education, Vermont, USA. Retrieved from https://files.eric.ed.gov/fulltext/ED310679.pdf

Steinberg, K. S., \& Norris, K. E. (2011). Assessing civic mindedness. Diversity and Democracy: Civic Learning for Shared Future, 14(3), 12-14. 
Stewart, T. (2012). Classroom teacher leadership: Servicelearning for teacher sense of efficacy and servant leadership development. School Leadership \& Management, 32(3), 233259.

Teddlie, C., \& Tashakkori, A. (2003). Major issues and controveries in the use of mixed methods in the social and behvioral sciences. In A. Tashakkori \& C. Teddlie (Eds), Handbook of mixed methods in social \& behavioral research (pp. 3-50). Thousand Oaks, CA: Sage.

Teranishi, C. S. (2007). Impact of experiential learning on Latino college students' identity, relationships, and connectedness to community. Journal of Hispanic Higher Education, 6(1), 52-72.

Tsang, M. C. (1997). The cost of vocational training. International Journal of Manpower, 18(1/2), 63-89.

Tucker, M. L., McCarthy, A. M., Hoxmeier, J. A., \& Lenk, M. M. (1998). Community service learning increases communication skills across the business curriculum. Business Communication Quarterly, 61(2), 88-99.

Tudor, J. (2013). An exploratory investigation into the context specific perceptions and practices of second year mechanical engineering undergraduates (Unpublished doctoral dissertation). Northumbria University, United KingdomUl-Haq, M. (2000). Human development in South Asia 1999: The crisis of governance. USA: Oxford University Press.

Ul-Haq, M., \& Haq, K. (Eds.). (1998). Human development report in South Asia 1998. Delhi, India: Oxford University Press.

Uzair-ul-Hassan, M., \& Noreen, Z. (2013). Educational mismatch between graduates possessed skills and market demands in Pakistan. International Education Studies, 6(11), 122-132.

Vandzinskaite, D., Mazeikiene, N., \& Ruskus, J. (2010). Educational impact of service-learning: Evaluation of citizenship and professional skills development. Socialiniai Mokslai, 3(4), 70-81.

Veloo, A., Md-Ali, R., \& Chairany, S. (2016). Using cooperative teams-game-tournament in 11 religious school to improve mathematics understanding and communication. Malaysian Journal of Learning and Instruction, 13(2), 97-123.

Wang, Y., \& Jackson, G. (2005). Forms and dimensions of civic involvement. Michigan Journal of Community Service Learning, 11 (2), 39-48. 
Warren, J. L. (2012). Does service-learning increase student learning? A meta-analysis. Michigan Journal of Community Service Learning, 18(2), 56-61.

Waterman, A. S. (2014). Service-learning: Applications from the research. New York, NY: Routledge. 